University of Nebraska - Lincoln

DigitalCommons@University of Nebraska - Lincoln

8-1974

\title{
Herpetomonas megaseliae: Architectural Rearrangements during Amastigote Formation
}

John J. Janovy Jr.

University of Nebraska - Lincoln, jjanovy1@unl.edu

P. M. Daggett

University of Nebraska - Lincoln

K. W. Lee

University of Nebraska - Lincoln

Follow this and additional works at: https://digitalcommons.unl.edu/bioscijanovy

Part of the Parasitology Commons

Janovy, John J. Jr.; Daggett, P. M.; and Lee, K. W., "Herpetomonas megaseliae: Architectural Rearrangements during Amastigote Formation" (1974). John Janovy Publications. 35.

https://digitalcommons.unl.edu/bioscijanovy/35

This Article is brought to you for free and open access by the Papers in the Biological Sciences at DigitalCommons@University of Nebraska - Lincoln. It has been accepted for inclusion in John Janovy Publications by an authorized administrator of DigitalCommons@University of Nebraska - Lincoln. 


\section{RESEARCH NOTES}

\section{Herpefomonas megaseliae: Architectural Rearrangements during Amastigote Formation}

The ultrastructure of Herpetomonas megaseliae Daggett, Dollahon, and Janovy, 1972, culture forms has been described in detail by Janovy et al. (1974, J. Prot. 21: 53-59). Pellicular microtubules were described in proand opisthomastigotes as parallel to the longitudinal axis of the body and to the axis of the flagellar pocket. Microtubules lay in an electron translucent zone directly beneath the limiting membrane, and the flagellar pocket opened at the anterior end.

Unpublished studies in this laboratory have indicated that Herpetomonas megaseliae and a number of other "lower" trypanosomatid parasites are capable of transforming into amastigotelike forms upon phagocytosis by murine macrophages in vitro. This note describes general architectural alterations and pellicular microtubule rearrangements associated with this transformation in Herpetomonas megaseliae, and compares the observed alterations with those occurring in Leishmania donovani under identical conditions in this laboratory.

Herpetomonas megaseliae, stock from this laboratory, and Leishmania donovani, $2 \mathrm{~S}$ strain (see Stauber, 1966, Exp. Parasit. 18: 1-11) were maintained in screw-cap tubes in Mansour's and Tanabe's medium, respectively (Daggett et al., 1972, J. Parasit. 58: 946-949; Janovy, 1967, Exp. Parasit. 20: 51-55). Peritoneal exudate cells were harvested from female C57B/6J mice according to the methods of Mauel and Defendi (1971, Exp. Cell Res. 65: 33-42). McCoy's 5A medium (GIBCO) with $30 \%$ fetal bovine serum was used as the harvesting and culture medium. Large phagocytic cells in the exudate were counted by hemocytometer, the cell suspension was diluted to contain approximately $10^{6}$ phagocytic cells $/ \mathrm{ml}$, and $2 \mathrm{ml}$ of the suspension was dispensed to Leighton tubes with or without cover slips. Approximately $2 \times 10^{6}$ parasites in $0.25 \mathrm{ml}$ Mansour's or Tanabe's medium were added to each siliconized Leighton tube. Infected cell cultures were maintained at $35 \mathrm{C}$ for $24 \mathrm{hr}$, infected cells were harvested from tubes without cover slips by centrifugation at $500 \mathrm{~g}$ for $5 \mathrm{~min}$, and fixed in $0.1 \mathrm{M}$ phosphatebuffered $3 \%$ glutaraldehyde for $2 \mathrm{hr}$ at room temperature. Subsequent preparations for electron microscopy were done exactly as described by Janovy et al. (1974, loc. cit.).

With the light microscope, murine macrophages on Giemsa-stained cover slips from cultures prepared as above could be seen to contain a variety of parasite morphological types from elongate to round, regardless of the parasite species used. In addition, some extracellular forms were observed in all cultures. These observations are similar to those of other workers who have used Leishmania-infected cell cultures (Akiyama and Taylor, 1970, Am. J. Trop. Med. Hyg. 19: 747-754). Electron micrographs of $H$. megaseliae- and $L$. donovaniinfected cells revealed parasites in parasitophorous vacuoles in all stages of transformation from near culture form to amastigote. In $H$. megaseliae, elongate intracellular forms, evidently recently phagocytized, retained a flagellar pocket parallel to the long axis of the parasite and parallel to the nonspirally arranged pellicular microtubules, as illustrated for culture forms (Janovy et al., 1974, loc. cit.). Amastigotes, however (Fig. 1), showed circular profiles of pellicular microtubules in the pellicle on one side of a parasite sectioned through the flagellar pocket. Invariably, in amastigotes, the circular profiles of microtubules to one side of the flagellar pocket were not matched by circular profiles on the other side, but rather by the parallel lines indicative of longitudinal sections of microtubules (Fig. 1). Intermediate forms, resembling Akiyama and McQuillen's figure 1 of L. donovani (1972, Am. J. Trop. Med. Hyg. 21: 873-879), were seen, and pellicular microtubule arrangements of these forms suggested that amastigote formation in $H$. megaseliae involved a rearrangement of the body architecture in which two elongate structures (pellicular microtubules and flagellar pocket), which had previously been 


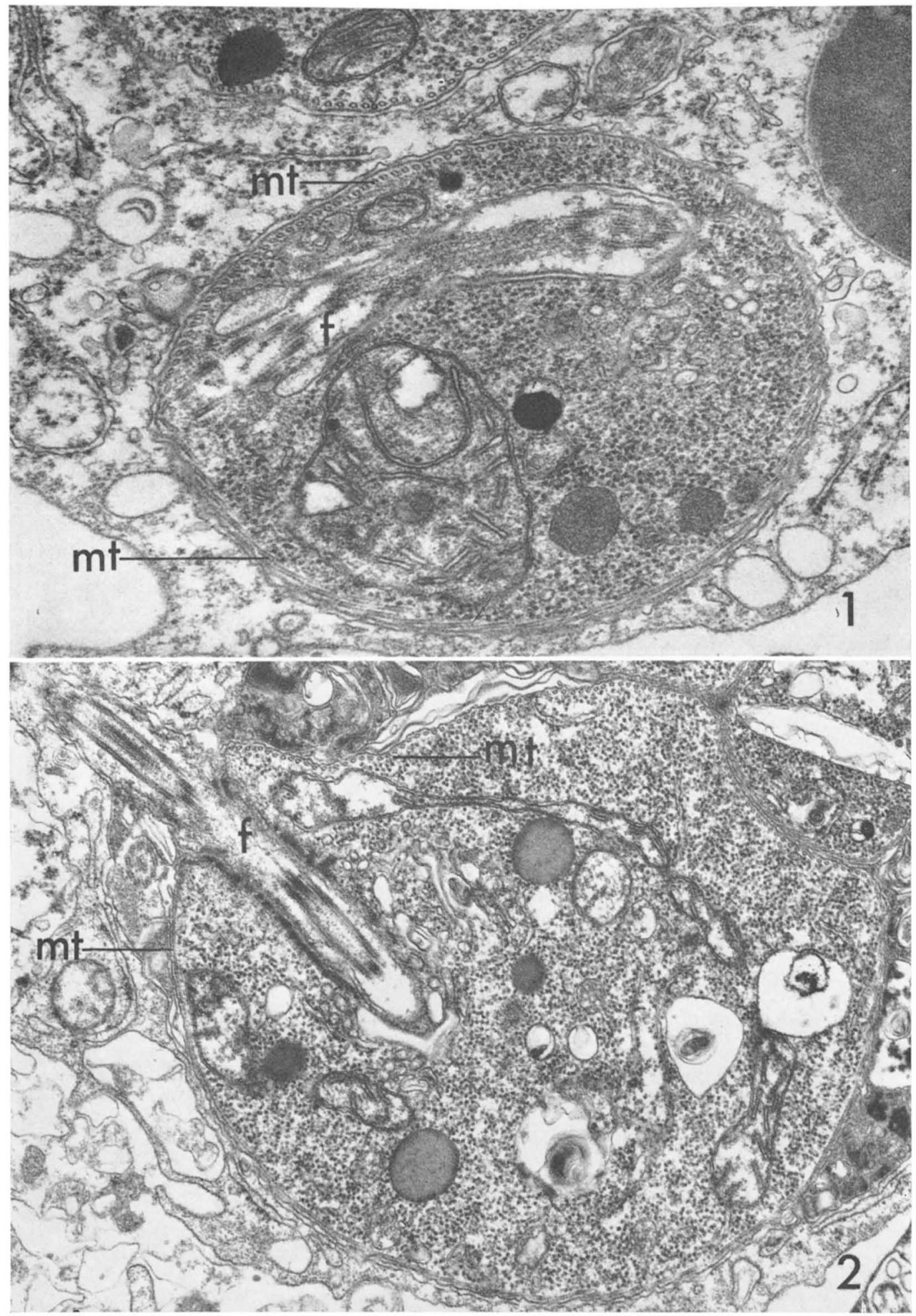

Figures 1, 2. Amastigotes in murine macrophages. 1. Herpetomonas megaseliae. 2. Leishmania donovani. f-flagellar pocket; mt-pellicular microtubules. 
parallel, became at least in part perpendicular, as if the flagellar pocket opening had migrated or been pushed to the midsection of the animal and the pocket's relative axis position had been altered by $90^{\circ}$. However, since on one side of the flagellar pocket the microtubules remained parallel to it, most likely originally parallel and relatively straight microtubules of the culture form became spirally arranged in the amastigote. The type of rearrangement of body architecture described here is not confined to $H$. megaseliae, since electron micrographs of $L$. donovani-infected cells also revealed similar microtubule-flagellar pocket relationships (Fig. 2). The pellicular microtubule arrangements cannot be readily determined from the published photos in the classic $L$. donovani work of Rudzinska et al. (1964, J. Prot. 11: 166-191). However, figures 1, 3 , and the upper right amastigote of figure 4 of Akiyama and McQuillen (1972, Am. J. Trop. Med. Hyg. 21: 873-879) show pellicular microtubule arrangements in the vicinity of the flagellar pocket of $L$. donovani amastigotes very similar to those reported here for $H$. megaseliae and $L$. donovani. Many electron micrographs of sections through the flagellar pocket of both species' amastigotes have been taken in this laboratory and have never failed to reveal the above-described microtubuleflagellar pocket relationship. If the microtubules are elastic, their spiral arrangement in the amastigote may be analogous to a coiled spring. Thus transformation into a promastigote may involve a process not unlike the release of tension on such a spring.

J. Janovy, Jr., P. M. Daggett, and K. W. Lee, School of Life Sciences, University of Nebraska, Lincoln, Neb. 68508 . Studies supported in part by U. S. A. Med. R. \& D. Contract DADA17-69-C9122. Statements herein are not to be considered official Department of Army position unless so stated in other authorized documents. 